Voyages

READERS OF PMLA RECOGNIZE 26 BROADWAY, IN NEW YORK CITY, AS

THE HEADQUARTERS OF THE MLA, ONE OF THE MAJOR HUBS OF INTEL-

lectual work in literary and cultural studies in North America. But in the summer of 1840,26 Broadway was a commercial hub that connected the world of the Atlantic Ocean with the world of the Indian Ocean. Here, in the offices of the New York firm Barclay and Livingston, Ahmad Bin Na'aman, special envoy of the sultan of Zanzibar; Sayyid Said, offered for sale merchandise that had been brought to the United States from Muscat and Zanzibar. The merchandise included " 1,300 bags of dates, 21 bales of Persian wool carpets and 100 bales of Mokha coffee" that had been acquired at Muscat and "108 prime ivory tusks, 81 cases of gum copal, ... 135 bags of cloves and 1,000 dry salted hides" from Zanzibar (Eilts 32). The cargo had come to New York on 30 April 1840 aboard the Sultanah, a bark owned by the sultan and commanded by William Sleeman, an Englishman. Except for two Frenchmen whose identities are uncertain and two Englishwomen who had sought passage to London, where the ship was headed, most of those on board were African slaves belonging to the ship's officers and hired lascars, Muslim seamen from the lower Konkan and Malabar coasts of India who had been signed on in Bombay, where the ship had been refitted for the transatlantic voyage and from which it first embarked (3). The slaves, we are told, were dressed in garments made of coarse cotton cloth "called meri$k a n i$, after the country of its manufacture" (4). In his account of the voyage of the Sultanah, Hermann Frederick Eilts writes of "the pungent vapors of cloves, gum copal and coffee (from the ship's cargo), of tar and pitch, of open-hearth cooking in deep, acrid sheep tail's fat, called ghee, of primitive shipboard sanitation and of coconut oil" (4). 'This account of the "first Arab emissary and the first Arab vessel to visit American shores" is a rich reminder of the historical interconnections in the world (6). ${ }^{2}$ theories and methodologies

\section{Oceans Connect: The Indian Ocean and African Identities}

GAURAV DESAI

GAURAV DESAl is a fellow at the National Humanities Center in North Carolina. Author of Subject to Colonialism: African SelfFashioning and the Colonial Library (Duke UP, 2001), he teaches in the Department of English at Tulane University. 
My interest in the voyage of the Sultanah stems from my ongoing research on the long-term historical and cultural connections between eastern and southern Africa and India. Such connections have existed since the time of the ancient civilizations of Egypt and Mohenjo Daro. Indian silk has been found among the wrappings of Egyptian mummies, and there is evidence of trade between Egypt and India for several centuries before the advent of Christianity. The first-century text Periplus of the Erythraean Sea, the Arab historian and geographer al-Masudi (d. 956), and the twelfth-century Arab geographer alIdrisi all refer to the maritime trade between the Indian and the East African coasts. The twelfth-century Indian Ocean trade has been documented by, among others, S. D. Goitein in his remarkable multivolume work $A$ Mediterranean Society, which draws on the documents and records found in the genizah of the Ben Ezra Synagogue in Cairo. This work prompted Amitav Ghosh to explore the implications of the early trade connections between India, Egypt, and the Middle East for the movements of people between these spaces in our time (see also Desai). While the traffic in human and other cargo continued throughout history with, for instance, the acquisition of Habshi (Abyssinian, or Ethiopian) slaves by Muslim rulers in India; the import of gold, ivory, precious stones, pearls, and metals from the Swahili and Sofala coasts to Gujarat; and the export of Indian cloths to East Africa, the volume of trade and the movement of peoples between these points in the Indian Ocean escalated in the nineteenth century (Ali; Harris, African Presence and Global Dimensions; Jayasuriya and Pankhurst; Sheriff; Prestholdt). The increase in such traffic coincided with the ascendancy in Zanzibar of the Omani sultanate, which by 1832 had gained suzerainty in the region. Meanwhile, the French had already recruited Indian indentured labor for plantations on the island of Réunion, and the flow of Indian indentured laborers to the neighboring island of Mauritius increased with the end of slavery there in 1834. On 16 November 1860 , the Truro, the first ship carrying Indian indentured laborers from Calcutta, reached Durban, in Natal, South Africa. As happened throughout the region, the arrival of indentured laborers was accompanied by the arrival of independent artisans and tradesmen, referred to in South African parlance as "passenger Indians."

As the lascar crew of the Sultanah and the ship's manufacture in the port city of Bombay suggest, Zanzibar in the nineteenth century found itself at a crossroads of commerce and culture. Its residents included indigenous Africans, Omani and Hadramatiti Arabs, members of several Indian communities, and smaller numbers of others such as Comoronians, Europeans, and Americans. The few American merchants, primarily from Salem, played a disproportionately significant role in the ongoing Indian Ocean trade. Indeed, so significant was this role that the United States Senate ratified a trade treaty with Sul$\tan$ Said on 30 June 1834 giving the United States de facto favored-nation status (Eilts 13). Eilts notes that between September 1832 and May 1834 " 32 out of 41 foreign vessels visiting the port [of Zanzibar] had been of American registry. They totaled 5,497 tons. Twenty of these vessels had hailed from Salem, three each from New York and Boston and the remainder from unspecified American ports. In contrast, seven British vessels had called during this period and one each from France and Spain" (14). In recognition of the importance of this trade and in accordance with the treaty, the United States began to appoint merchant consuls in Zanzibar. The first, Richard Waters of Salem, took office in 1837. ${ }^{3}$

After the Salem trade with Zanzibar had flourished for three decades, the American Civil War initiated its demise. The logistics of obtaining southern cotton in the North during the war directly affected the export of that commodity. The Civil War also tar- 
geted oceanic commerce, leaving a mark on South African popular culture that continues today. On 2 January each year, members of the Cape Malay and "colored" communities of Cape Town take to the streets in a carnival that celebrates the arrival of the new year and, as some scholars have suggested, emancipation from slavery. An important part of this carnival is the singing of songs inspired by minstrel shows dating back in South Africa to the American visits to Cape Town of Christy's Minstrels, in 1862, and the Virginia Jubilee Singers, who stayed in the Cape from 1890 to 1892 and returned in 1895 (Martin $82-91$ ). One of the songs popularly sung by the minstrel groups to this day is "Daar Kom die Alabama" "There Comes the Alabama"), referring to a Confederate raiding ship that sailed into Cape Town on 5 August 1863, triumphantly towing the Sea Bride, a captured Union ship. The Alabama's arrival in Table Bay seems to have caused much excitement in Cape Town, inspiring the song that has survived for generations in this carnival tradition (Bradlow and Bradlow 11-15, 116-18).

In drawing attention to the voyages of the Sultanah and the Alabama, I aim to do at least two things. First, I want to suggest that North American readers should have a direct interest in the histories and cultures of the Indian Ocean since their own histories are implicated in it. The dominant tendency in North American research on Africa and its diaspora is to gravitate toward the connections between western Africa and the New World across the Atlantic. While there is good reason to do so, one shouldn't assume that no commerce between the Americas and the world of the Indian Ocean took place; slaves, for instance, were transported from Mozambique to Brazil (Newitt). Consider this irony of the Salem trade connections: slave labor brought from Africa to the United States helped produce cotton that was manufactured into so-called amerikani cloth, which was shipped by Salem merchants to Zanzibar for trade. In Zan- zibar the cloth was subject to a five percent customs duty, levied on behalf of the sultan by his Indian customs officer, Jairam Sewji. With other Indian merchants, Sewji also arranged for the acquisition of exports to the United States from the region. Sewji, who paid an annual fee to the sultan for running the customs house, accrued significant profits as customs master. He and other Indian traders used some of their profits not only to fund (primarily Arab) trade caravans into the interior but also to supply logistical and financial support to European explorers who were mapping the interior. The Arab trade caravans were engaged in the acquisition and sale of copal and ivory, as well as slaves, in Zanzibar and in other ports of the Indian Ocean. The logistical support of Europeans, however, exposed a European audience to the cruelties of the slave trade, leading Britain to put forward to the sultan various treaties curtailing slavery. In the long term, this resulted in the economic downfall of the Omani sultanate, which drew much of its exchequer on the customs and profits associated with the trade.

My second aim in telling the story is to challenge the dominant reading of Africa as having somehow escaped or bypassed the processes of globalization. This reading echoes the empty historical slot assigned to Africa most famously by Hegel and disserves the complex negotiations of commerce, identity, and the advent of modernity performed by a multitude of actors on the African stage. Indeed, along with an increasing number of my Africanist colleagues, I argue that African globalization must be thought of in the context of a long history. The role of Africa in the Indian Ocean trade system is crucial to interrogating established readings of Africa. We are often inundated with arguments about the rise of European modernity as a case of Western exceptionalism. But the work of K. N. Chaudhuri, André Wink, Michael N. Pearson, Edward Alpers, Himanshu Prabha Ray, Sanjay Subrahmanyam, Janet 
Abu-Lughod, Andre Gunder Frank, and many other fellow travelers has mapped in considerable detail the Indian Ocean trading system that existed before Western economic supremacy. This body of research provides an excellent complement to the existing archive of knowledge on cross-Atlantic and Mediterranean encounters. While I sympathize with Indian Ocean scholars who ask us not to read the Indian Ocean through an Atlantic lens, I have nevertheless chosen to preface my comments with the Sultanah story, since it highlights the fact that despite the differences between the histories and cultures of the Indian Ocean and those of the Atlantic, as asserted in the memorable title of a Ford Foundation project held at Duke University in the late nineties, "Oceans Connect."

\section{Recasting African Identities}

Spanning over six thousand miles, from the southern tip of Africa to Australia, the Indian Ocean has been the site of travels and migrations for millennia and is without question a daunting subject of study. As an Africanist, I propose to narrow our focus by raising some questions in the rest of this essay about what paying attention to the movements of peoples and ideas across the Indian Ocean might mean to contemporary discussions of African cultural politics and identities. I am particularly interested in how attending to this history might entail revisioning the colonial encounter in Africa and reframing our discussions of the politics of African identities as those identities circulate in literary and cultural texts. Let us consider here a famous passage in Frantz Fanon's Wretched of the Earth that continues to inform the predominant discourse on colonialism in Africa:

The colonial world is a Manichean world. It is not enough for the settler to delimit physically, that is to say with the help of the army and the police force, the place of the native.
As if to show the totalitarian character of colonial exploitation the settler paints the native as a sort of quintessence of evil. Native society is not simply described as a society lacking in values. It is not enough for the colonist to affirm that those values have disappeared from, or still better never existed in the colonial world. The native is declared inaccessible to ethics; he represents not only the absence of values, but also the negation of values.

Fanon's vision of a starkly Manichean colonial world was to resonate with a number of nationalist intellectuals and writers in twentieth-century Africa who had, in the fifties and early sixties, fought the oppressive restrictions of colonial society in the hopes of yielding a socially just, independent future. Of the many literary critics of this generation who were inspired by Fanon, perhaps the most influential was Abdul JanMohamed, who published his study Manichean Aesthetics in 1983. Manichean Aesthetics sought to articulate a sociopolitical theory of literary production that took into account the racial divisions of the colonial world that Fanon had laid out. The European colonial writer, wrote JanMohamed, "sought to rationalize the whole imperial endeavour" and produced an ideology valorizing colonialism (2). In response, the African writer sought to demystify this ideology and spoke instead of the traumas of colonialism. Of interest to JanMohamed was not only the fictional shape that colonial ideology took but also its "negative influence" on African writing. "The dialectic of negative influence," wrote JanMohamed, "is in fact a literary manifestation of the Manichean socio-political relation between the colonizer and the colonized" (8).

In the colonial African contexts that interested him, JanMohamed would select for his study "three Europeans" and "three Africans" from three parts of the continent. His choice enabled him to present the typology of the Manichean aesthetic through a series of contrasts between white and black writers. 
Despite the book's emphasis on race and racial politics, Manichean Aesthetics maintains a curious silence on the nonblack, nonwhite subjects of Africa. Indeed, they are present in the introduction only as a literally parenthetical afterthought: "Gordimer's depiction of the effects of apartheid on the conscience of liberal white South Africans must be read in conjunction with La Guma's representation of the more drastic consequences of apartheid for the blacks (as well as 'Coloureds' and Indians)" (10; emphasis mine).

My interest in JanMohamed's bracketing of "Coloured" and "Indian" subjects in his account of the politics of literature in colonial Africa is not unrelated to the curious biographical fact that JanMohamed himself is a Kenyan of Indian heritage. Neither black nor white, JanMohamed belongs to a community that, as I suggested earlier, has had connections with eastern Africa for millennia. Along with the arrival of Arabs from Oman, the legacy of the Asian presence in East Africa has been the subject of much debate since colonial times." The more pernicious postcolonial manifestations of this debate include the looting of Asian shops in Nairobi, targeted assaults on Asians and Arabs during the Zanzibar revolution, and the mass expulsion of Asians from Uganda by Idi Amin. Whatever assessment we finally make about the role of Asians in Africa since before the beginning of formal European colonialism, the record is clear that, at least in British East Africa, colonialism was necessarily structured not through a simple division between "settler" and "native" but through a complex struggle between a variety of actors-the colonial authorities in England, the white settlers in East Africa (particularly Kenya), the Asians of East Africa, the colonial Indian government in India, and the so-called natives in the Fanonian framework, the black Africans of East Africa. Instead of reading colonialism as purely binary, we may in this context more usefully see it as an ideologically disjunctive and dispersed process. To be sure, the tropes of self and other that Fanon and JanMohamed employ in their reading of the cultures of colonialism are overwhelmingly present in this expanded terrain of social relations, but the particular valences of "good and evil, salvation and damnation, civilization and savagery, superiority and inferiority, intelligence and emotion" are not so easily mapped onto a white-black racial dichotomy (JanMohamed 4). ${ }^{8}$

Nevertheless, it is important to understand that JanMohamed's bracketing is not accidental but rather symptomatic of a generation of East African Asians who came of age in a newly postcolonial context. Many Asians in East Africa felt uncertain about their political and economic futures in the newly independent states. A few left with the arrival of independence. Some held on to their British passports to hedge their bets. Others promptly took up citizenship in the African countries of their residence. Such individual and family choices about future residence were accompanied by ideological and political tendencies. Many progressive intellectuals embraced the ideology of black consciousness and chose to identify with the newly independent nations and with their black fellow citizens. Hence, the trauma associated with an uncertain future was accompanied by a performative insistence on shared histories and political alliances. In this context, a book that dealt explicitly with the racialized structure of the colonial encounter could preserve a remarkable silence on its author's racial heritage. The Manichean, settler-native framework lent itself to a liberal hope that Asians and black Africans could both see themselves as natives. But the same Manicheanism on the streets often resulted in a reverse judgment. The question, indeed, was too divisive to pose in a still-developing academic analytic of colonial society. ${ }^{9}$

In her 1999 book Nomadic Identities, May Joseph, a Tanzanian Asian who resides in the United States, presents a moving account of being jarred while watching Mira 
Nair's Mississippi Masala in 1991. The film's depiction of a family fleeing Amin's Uganda brought back long-repressed memories of her own family's anxieties about the anti-Asian sentiments in Dar es Salaam in the 1970s. Meditating on the performance of citizenship, Joseph recalls her desperate attempts to expressively stage her citizenship by trying to get the ngoma dances just right, by deemphasizing the Asian accent in her Swahili, and by ensuring that her school assignment of maintaining the shamba, or vegetable garden, would make the mark. "Despite the anti-Asian graffiti present in the streets on the route home," she writes, "I was determined to prove that I had assimilated. But being defined inauthentic proved a more potent force than my expressive stances. Clearly, more was needed than speaking perfect Swahili-most important, a sense of historicity in relation to this transitioning place of 'Tanzanian socialist citizenship" (2).

If Mississippi Masala proved to be the most widely circulated depiction of the Ugandan exodus and drew attention to the plight of East Africa's Asians, it was preceded by the publication of Moyez Vassanji's novel The Gunny Sack, in 1989. While not the first novel to depict Asian communities in East Africa, it captured the attention of Africanists as well as a global anglophone readership. ${ }^{10}$ Vassanji is a literary giant in a growing tradition of Asian writing from Africa, having won the Giller Prize in 1994 for The Book of Secrets and a second Giller, in 2003, for The In-Between World of Vikram Lall. To name only a few others, the South African writers Ahmed Essop, Ronnie Govender, Deena Padayachee, Muthal Naidoo, Kriben Pillay, and Imraan Coovadia have provided a remarkable imaginative literature on the legacies of Asian settlement on the African continent. These legacies include the racial and cultural hybridity of the Indian Ocean world, most extensively thematized by writers such as Achmat Dangor and Farida Karodia, from South Africa, who are themselves of mixed- race heritage, and writers like Abdulrazak Gurnah, from Zanzibar, who trace their genealogy to the Arab migrations into eastern Africa. These writers' representation of creolized cultures resists the convenient but ultimately reductive binaries that often accompany our accounts of African identities.

The proliferation of literary works set in Asian, Arab, Cape Malay, and mixed-race communities in Africa since the nineties (and more prominently since the demise of apartheid in South Africa) has led critics to reexamine the politics of nation and narration in the Indian Ocean world of the African continent (Simatei; Kalliney; Rastogi; Hawley; Ojwang). Yet much more remains to be told of the lives of those-Indians, Arabs, indigenous Africans, mixed-race peoples - who found and continue to find themselves in the crosscurrents of Indian Ocean histories. To read the diversity of these lives through available narratives and to anticipate narratives yet to come are to call attention to the multiple legacies, histories, and identities that have long circulated in the world of the Indian Ocean. ${ }^{\text {II }}$

\section{NOTES}

1. Ghee is a form of clarified butter typically made from cow's or buffalo's milk. It is unclear whether the crew used the term ghee loosely or whether Eilts did not know the composition of the product.

2. Another reminder of the significance of the Indian Ocean trade is the replica of a cabin in the ship Taria Topan in which the Salem Marine Society still meets. Named in honor of the influential Zanzibari Indian trader Taria Topan, it sits on the rooftop of the historic Hawthorne Hotel in Salem, Massachusetts. For further accounts of the Salem trade with Zanzibar, see Browne; Brady; Prestholdt; Osgood. Also of interest are Bennett; Bennett and Brooks.

3. In the case of Richard Waters (1807-87), commerce was not disconnected from his desire to spread Christianity. In a letter to his brother on 17 December 1839, Waters wrote, "I feel quite confident that I shall have a missionary and his wife accompany me on my return to Zanzibar. The time has come for the introduction of the Christian religion into this dark portion of the earth. ..." Waters's papers illustrate the considerable travels under- 
taken by merchants not only between Salem and Zanzibar but also between other Indian Ocean ports such as Mombasa, Muscat, and Bombay. For instance, it appears from his letters that Waters was in Bombay in 1841 and again from at least 13 November 1844 to 28 January 1845. On 17 February 1845 he was in Mombasa, and, later that year, on 30 September, he was in Salem.

4. Martin provides the most detailed study of the Kaapse Karnaval, or Cape Carnival-more popularly, though not uncontroversially, called the Coon Carnival. He suggests that in the creolized world of Cape Town, the carnival evolved from a combination of the Dutch settlers' Christmas and New Year's celebrations with the street parades of ex-slaves who commemorated the day of emancipation, 1 December 1834 (49-64).

5. The literature on Africa and globalization in the longue durée is rapidly expanding. See, for instance, Harris, African Presence and Global Dimensions; Wright; Prestholdt; Ferguson; Zeleza.

6. The most vigorous debates about the importance of recognizing the differences between the Atlantic and Indian oceans revolve around the meanings and experiences of slavery. For a primer on the differences between Atlantic Ocean-world slavery and Indian Ocean-world slavery, see Campbell. The "Oceans Connect" project at Duke University was funded by the Ford Foundation in 1997 and brought together scholars working on the Atlantic, Pacific, and Indian oceans over a number of years. My thanks go to Ian Baucom and Charles Piot for inviting me to present my work in the seminar associated with this project.

7. The term Asians, as opposed to the more restrictive Indians, began to be used after the partition of India to refer to immigrants who had come to Africa from the Indian subcontinent.

8. I restrict my discussion here to East Africa. The specificities of the Indian presence in South Africa, Mauritius, Réunion, and other African places require alternative-though not entirely different-presentations.

9. There is a large literature associated with the Ugandan exodus as well as with the reading of Asians in East Africa at the time of independence. Theroux's 1967 piece is particularly provocative.

10. Works of Asian fiction from East Africa that preceded Vassanji's novel include Bahadur Tejani's Day after Tomorrow (1971) and Peter Nazareth's In a Brown Mantle (1972) and The General is Up (1984).

11. This is one of the tasks of my current book project, tentatively titled "Post-Manichean Aesthetics: $A$ frica and the Indian Ocean Imagination."

\section{WoRKs Cited}

Abu-Lughod, Janet. Before European Hegemony: The World System, A.D. 1250-1350. New York: Oxford UP, 1989. Print.
Ali, Shanti Sadiq. The African Dispersal in the Deccan. Bombay: Orient Longman, 1995. Print.

Alpers, Edward. Ivory and Slaves: The Changing Pattern of International Trade in East Central Africa to the Later Nineteenth Century. Berkeley: U of California P, 1975. Print.

Bennett, Norman Robert, ed. The Zanzibar Letters of Edward D. Ropes, Jr, 1882-1892. Boston: African Studies Center, Boston U, 1971. Print.

Bennett, Norman Robert, and George E. Brooks, Jr., eds. New England Merchants in Africa: A History through Documents, 1802-1865. Boston: Boston UP, 1965. Print.

Bradlow, Edna, and Frank Rosslyn Bradlow. Here Comes the Alabama: Cape 'Town: Balkema, 1958. Print.

Brady, Cyrus Townson, Jr. Commerce and Conquest in East Africa, with Particular Reference to the Salem Trade with Zanzibar: Salem: Essex Inst., 1950. Print.

Browne, J. Ross. Etchings of a Whaling Cruise, with Notes of a Sojourn on the Island of Zanzibar. New York: Harper, 1846. Print.

Campbell, Gwyn, ed. The Structure of Slavery in Indian Ocean Africa and Asia. Portland: Cass, 2004. Print.

Chaudhuri, K. N. Trade and Civilization in the Indian Ocean: An Economic History from the Rise of Islam to 1750. New York: Cambridge UP, 1985. Print.

Coovadia, Imraan. Green-Eyed Thieves. Roggebaai: Umuzi, 2006. Print.

- The Wedding. New York: Picador, 2001. Print.

Dangor, Achmat, Bitter Fruit. Cape Town: Kwela, 2001. Print.

- Kafka's Curse. Cape Town: Kwela, 1997. Print.

Desai, Gaurav. "Anthropology, History, and the Writing of Nostalgia: A mitav Ghosh's Old World Order." Representations 85 (2004): 125-48. Print.

Eilts, Hermann Frederick. Ahmad Bin Na'aman's Mission to the United States in 1840: The Voyage of al-Sultanah to New York City. Oman: Petroleum Dev. Ltd., 1971. Print. Rpt. from Essex Institute Historical Collections 98.4 (1962): 219-77. Print.

Essop, Ahmed. The Emperor. Johannesburg: Ravan, 1984. Print.

- Hajji Musa and the Hindu Firewalker. Columbia: Reader's IntI., 1988. Print.

Fanon, Frantz. The Wretched of the Earth. New York: Grove, 1963. Print.

Ferguson, James. Global Shadows: Africa in the Neoliberal World Order. Durham: Duke UP, 2006. Print.

Frank, Andre Gunder. ReOrient: Global Economy in the Asian Age. Berkeley: U of California P, 1998. Print.

Ghosh, Amitav. In an Antique Land. New York: Knopf, 1993. Print.

Goitein, S. D. A Mediterranean Society: The Jewish Communities of the Arab World as Portrayed in the 
Documents of the Cairo Gentiza. 6 vols. Berkeley: $\mathrm{U}$ of California P, 1967-93. Print.

Govender, Ronnie. The Lahnee's Pleasure. Johamnesburg: Ravan, 1980. Print.

- Song of the Atman. Johannesburg: Jacanda, 2006. print.

Gurnah, Abdulrazak. Desertion. New York; Pantheon, 2005. Print.

- Paradise. London: Penguin, 1994. Print.

Harris, Joseph. The African Presence in Asia: Consequences of the East African Slave Trade. Evanston: Northwestern UP, 1971. Print.

- ed. The Global Dimensions of the African Diaspora. 2nd ed. Washington: Howard UP, 1993. Print.

Hawley, John C., ed. India in Africa, Africa in India: Indian Ocean Cosmopolitanisms. Bloomington: Indiana UP, 2008. Print.

Idrisi, al-, India and the Neighbouring Territories in the Kitab Nuzhat al-Mushtq Fi'khtiraq al-afaq of alSharif al-Idrisi: A Translation, with Commentary, of the Passages Relating to India, Pakistan, Ceylon, Parts of Afghanistan, and the Andaman, Nicobar, and Maldive Islands, Etc. Trans. S. Muqbal Ahmad. Leiden: Brill, 1960. Print.

JanMohamed, Abdul, Manichean Aesthetics: The Politics of Literature in Colonial Africa. Amherst: U of Massachusetts $P, 1983$. Print.

Jayasuriya, Shihan de, and Richard Pankhurst, eds. The African Diaspora in the Indian Ocean. Trenton: Africa World, 2003. Print.

Joseph, May. Nomadic Identities: The Performance of Citizenship. Minneapolis: U of Minnesota P, 1999. Print.

Kalliney, Peter, "East African Fiction and Globalization." Options for Teaching the African Novel. Ed. Gaurav Desai. New York: MLA, 2009. 259-73, Print.

Karodia, Farida. Other Secrets. Johannesburg: Penguin, 2000. Print.

Martin, Denis-Constant. Coon Camival: New Year in Cape Town. Cape Town: Philip, 1999. Print.

Masudi, al-. The Meadows of Gold, the Abbasids. Trans. Paul Lunde and Caroline Stone. New York: Paul, 1989. Print.

Naidoo, Muthal. Jail Birds and Others. Joubert Park: Botsotso, 2004. Print.

Nair, Mira, dir. Mississippi Masala. Columbia, 1991. Film.

Nazareth, Peter. The General Is Up. Calcutta: Writers Workshop, 1984. Print.

—. In a Brown Mantle. Nairobi: East African Lit. Bureau, 1972. Print.

Newitt, Malyn. A History of Mozambique. Bloomington: Indiana UP, 1995. Print.

Ojwang, Dan Odhiambo. "Writing Migrancy and Ethnicity: The Politics of Identity in East African Indian Literature." Diss. U of the Witwatersrand, 2004. Print.
Osgood, Joseph B. F. Notes of Travel; or, Recollections of Majunga, Zanzibar, Muscat, Aden, Mocha, and Other Eastern Ports, Salem: Creamer, 1854. Print.

Padayachee, Deena. What's Love Got to Do with It? Johannesburg: COSAW, 1992. Print.

Pearson, Michael N. Port Cities and Intruders: 'The Swahili Coast, India, and Portugal in the Early Modern Era. Baltimore: Johns Hopkins UP, 1998. Print.

The Periplus of the Erythraean Sea by an Unknown Author, with Some Extracts from Agatharkhides on the Erythraean Sea. Ed. and trans. G. W. B. Huntingford. London: Hakluyt Soc., 1980. Print.

Pillay, Kriben. Looking for Muraga. U of Durban, Westville: Asoka Theatre, 1995. Print.

Prestholdt, Jeremy. Domesticating the World: African Consumerism and the Genealogies of Globalization. Berkeley: U of California P, 2008. Print.

Rastogi, Pallavi. Afrindian Fictions: Diaspora, Race, and National Desire in South Africa. Columbus: Ohio UP, 2008. Print.

Ray, Himanshu Prabha. The Winds of Change: Buddhism and the Maritime Links of Early South Asia. Delhi: Oxford UP, 1994. Print.

Ray, Himanshu Prabha, and Edward Alpers, eds. Crosscurrents and Community Networks: The History of the Indian Ocean World. Delhi: Oxford UP, 2007. Print.

Sheriff, Abdul. Slaves, Spices, and Ivory in Zanzibar: Integration of an East African Commercial Empire into the World Economy, 1170-1873. London: Currey, 1987. Print.

Simatei, Tirop P. The Novel and the Politics of Nation Building in East Africa. Bayreuth: Breitinger, 2001. Print.

Subrahmanyam, Sanjay. Merchant Networks in the Early Modern World. New York: Variorum, 1996. Print.

Tejani, Bahadur. Day after Tomorrow. Nairobì: East African Lit. Bureau, 1971. Print.

Theroux, Paul. "Hating the Asians." Transition 33 (1967): 60-73. Print.

Vassanji, Moyez. The Book of Secrets. London: Picador, 1994. Print.

—. The Gunny Sack. New York: Heinemann, 1989. Print.

- The In-Between World of Vikram Lall. New York: Knopf, 2003. Print.

Waters, Richard. Papers. 1831-39. MH 14, MS 2, folder 3. Phillips Lib., Peabody Essex Museum, Salem.

Wink, André. Al-Hind: The Making of the Indo-Islamic World. New York: Brill, 1990. Print.

Wright, Donald. The World and a Very Small Place. Armonk: Sharpe, 1997. Print.

Zeleza, Paul Tiyambe. The Intellectual Challenges. Trenton: Africa World, 2003. Print. Vol. 1 of Rethinking Africa's Globalization. 